\title{
Job satisfaction and commitment in the entrepreneurial SME
}

\author{
Gary Akehurst · José Manuel Comeche • \\ Miguel-Angel Galindo
}

Accepted: 11 March 2008/Published online: 23 April 2008

(C) Springer Science+Business Media, LLC. 2008

\begin{abstract}
In the current global corporate climate that surrounds us, firms would do well to encourage the talent and creativity of their employees to achieve success. This is achieved, not by giving priority to individual talent, but by optimizing the collective as a whole and with the firm's activities based on teamwork and joint effort. Heads of organizations might benefit from creating a favorable context for the birth and growth of collective internal cooperation, which is understood to be the collective ability to create and innovate on the part of the team, the firm or the organization. Having contrasted our hypotheses through research on Spanish firms, we have concluded that job satisfaction and commitment to the team are factors that have a direct and positive effect on Internal Entrepreneurship.
\end{abstract}

G. Akehurst

RMS The Erasmus University, Rotterdam,

The Netherlands

e-mail: ga@akehurstonline.co.uk

J. M. Comeche

University of Valencia, Valencia, Spain

e-mail: jose.m.comeche@uv.es

M.-A. Galindo ( $\square)$

Applied Economics, University of Castilla-La Mancha, Avenida de Europa, 11 B, Pozuelo de Alarcon,

Madrid 28224, Spain

e-mail: mgalindo@teleline.es
Keywords Attitude - Internal Entrepreneurship · Job satisfaction - Individual talent - Commitment . Innovation

JEL Classifications L26

\section{Introduction}

While we continue to foment the idea of the traditionally heroic figure of the solitary entrepreneur, we are in danger of slowing down the process of change and adaptation which are so essential to our economic success. If firms want to remain competitive in today's climate, they should begin by promoting internal collective cooperation (within their own organizations), on the basis that the joint effort of all organizational members is greater than the sum of its individual contributions. We need to provide more incentives for our teams and reduce the aggressive nature of the leader's role, while at the same time reducing individual geniality. We are referring to a topic which has not been the subject of a great deal of research and which is inextricably linked to internal collective cooperation within the firm, its teams, and its leadership. In the global, modern business world, with a view to achieving success, firms can often benefit from encouraging the talent and creativity of their employees, and not just the individual innovator. Internal cooperation does not refer to a chosen few but to the entire collective, to activity based on 
teamwork and to the result of joint effort. Today, heads of organizations are required to carry out a far more important task: creating a favorable context for the birth and growth of internal collective cooperation, otherwise described as the collective capacity to create and innovate on the part of the team, the firm, or the organization.

\section{Internal entrepreneurship as a new organizational focusing}

There is no guarantee that entrepreneurship on an individual level will be automatically transferred into a collective one (Reich 1987). In accordance with this fact, we will attempt to ascertain what the enabling elements of Internal Entrepreneurship are and what influence they exert (Casson and Wadeson 2007; McMullen et al. 2007). We will investigate which are the elements that enable the appearance, existence, and continuation of the entrepreneurial spirit in a work team environment. Above all, we will attempt to expose which variables form the necessary base for promoting and developing those group entrepreneurial activities carried out within the context of a small and mediumsized enterprise (SME) and the extent of their relevance in explaining the existence of Internal Entrepreneurship in the firm. These variables are related to collaborators (team members) from the point of view of attitude and behavior, as well as to a particular style of leadership. Parting from the perspective of attitude, in this study we will focus our attention on determining which variables are relevant and the degree of impact they have on Internal Entrepreneurship.

Internal Entrepreneurship is related to the concept of entrepreneurial teams of employees (Stewart 1989). This may be rather unconventional, but it is consistent with the opportunity-centered interpretation of entrepreneurship. This interpretation does not center on individuals and personalities, so the concept of Internal Entrepreneurship redirects attention away from the popularly held conceptions of the "entrepreneur as hero" (Reich 1987). We define Internal Entrepreneurship as an emerging synergism of a collective that drives an organization to its present state, giving dimensions for opportunities without taking into account the resources available at that moment (Stevenson and Jarillo 1990). Economic literature has traditionally understood entrepreneurship to be the creation of a firm that begins with a hierarchy under the control of the businessperson (Dyer 1994; Westhead and Wright 1998). However, since the 1980s, there has been a plethora of studies appearing in the management literature from a new perspective on entrepreneurship, what has come to be known as intrapreneurship. This is understood to be a process which does not necessarily come from the top, but which may start at the bottom of the hierarchical scale and gradually work its way up. The term intrapreneurship distinguishes itself from the traditional concept of entrepreneurship basically in the sense that the process of innovation (which includes the function performed by the business) is carried out within the context of existing organizations (Huse et al. 2005). However, there is another difference regarding the environment which surrounds the intracorporate or intrapreneurial process, as the intracorporate process is not subject to the pressure of a competitive process, but is selected and recognized within an organizational structure.

Pioneering surveys by Gartner (1990) on the topic, applied as much to researchers as to company bosses, show that the applicability of the idea of the businessman merely as founder, owner, and manager is considered to be too elementary. Several studies (Carland et al. 1984; Gartner 1989, 1990; Darroch et al. 2005; Zampetakis and Moustakis 2006) have attempted to extend the definition of entrepreneurial spirit as the distinction between innovative businesspeople inside and outside existing organizations. Research, such as that of Sharma and Chrisman (1999), proposes a definition of entrepreneurship which is highly consistent with that of some traditional and highly respected authors such as Schumpeter (1934) and with the intra-corporate process (intrapreneurship), also known as corporate entrepreneurship (Zahra 1993). This school of thought identifies businessmen as individuals, or groups of individuals that act, either individually or as part of a corporate system, that create new organizations, or instigate renewal or innovation of an already existing organization (Sharma and Chrisman 1999). On innovate experiments see Govindajaran and Trimble (2006) and on innovation process in small firms, see Fukugawa (2006), HewittDundas (2006), and Scott (2006).

An enormous variety of concepts describe entrepreneurial efforts within an already existing organization: 
corporate entrepreneurship, intellectual entrepreneurship, community entrepreneurship, industrial districts, team entrepreneurship, partnership, virtual organization, cooperatives, family businesses, and intrapreneurship. However, the most interesting characteristic within this classification, in our case, is that the presence of innovation as a necessary condition for Internal Entrepreneurship within the organization is perceived as an act of creative collaboration. Currently, a great number of organizations design their competitive advantages, not based mainly on initiatives of their CEOs and on individual ingenuity, but on the continued innovation and refinement of ideas created in the workplace. There is a large element of what has come to be termed knowledge management. In large firms, the individual businessperson has been replaced with the businessperson within the team, where the "top teams" are recognizable more by their functions than by the personality of their members. In fact, many organizations should put an end to the "myth of the entrepreneurial hero" and give recognition to Internal Entrepreneurship (organizational entrepreneurship) that emerges from synergetic contributions between and from employees. Along the same lines, Bennis and Biederman (1998) incorporate the term "large groups," suggesting that big groups will sacrifice individuality, even if the individual shows ingenuity, if it needs to ensure an atmosphere of cooperation, given that, what takes precedence, even over individual ingenuity, is shared information and mutual stimulation resulting from joint effort.

The popular image of entrepreneurship is linked to the individual businessman and to small firms in the form of new creation, or in situations where the organization is already functioning, to the entrepreneur, though this is almost and always associated with family businesses and based on the efforts of a sole element (Johannisson 2003). However, we are witnessing the rethinking of the function of the individual businessperson and of the desire on the part of the management of large firms to create a business atmosphere, or intrapreneurship, within the firm (Pinchot 1985). This leads us on to the current idea of corporate entrepreneurship, perceived as the attitude and actions of the manager-businessman or businesswoman toward the inner workings of the firm. However, we can suggest that the number of forms of entrepreneurship can differ according to the number of business ventures undertaken at any one time and according to the number of agents who develop these ventures (entrepreneurs), or indeed due to the need for compensation on the part of the entrepreneur for previous failed projects. On the other hand, traditional research on entrepreneurship (Rosa and Scott 1999) underlines the importance of the entrepreneurial function and the entrepreneurial process together, and not that of the individual business as the focus of analysis. On a different note, the term Internal Entrepreneurship is linked to the existence of groups of individual entrepreneurs involved in the development of the business, while maintaining the organization and freedom of the individual. This idea is more closely related to the terms "mutual help," solidarity, and shared feelings. Moreover, forms of Internal Entrepreneurship can differ with respect to particular factors, such as organizational structure, the extent and/or formalization of tasks among organizational units, the physical and social proximity of agents involved in a process etc. (Johannisson 2003).

Internal Entrepreneurship thus occurs when the whole of the effort is greater than the sum of the individual contributions. Internal entrepreneurship is a venture based on the efforts of the team by turning to the talent and creativity of each one of its members. Good collaboration reflects the ability of people to work together for their mutual benefit (Scott 1999). Stewart (1989) uses the analogy of soccer to explain the importance of mutual understanding among team members when working together to produce collective outcomes. In this way, entrepreneurship is not only the domain of the founding member of the organization or its managing directors but a capacity that is spread throughout the collective, albeit within a team or organization, that experiments with and develops new systems for capturing and building knowledge and accumulated experience via its members. Business projects in work teams are aimed at creating countless new small ideas that help members to themselves bring out in the skills acquired, with a view to responding to the ever-increasing and changing demands of markets.

Internal Entrepreneurship implies a constant improvement which involves everyone (managers and workers) in unison (Imai 1986). The sum of individual intelligence within an organization or 
team allows both the group and the individual to innovate and adapt in a creative way. In line with this definition, both the collective capacity to identify opportunities, as well as the collective capacity to respond to these opportunities, are important components in Internal Entrepreneurship. In short, the capability and creativity of one individual entrepreneur is always limited. Working together, members of an organization (SME) could also contribute to innovation, although Internal Entrepreneurship is not adequately recognized because western culture tends to identify individual heroes without giving recognition to group contributions, and also due to the fact that the academic world has not devoted a great deal of attention to the collective effort. As little attention or research has focused on Internal Entrepreneurship; our aim is to add a scientific approximation to this situation, underlining group attitudes and behavior required for Internal Entrepreneurship in an organization and analyzing how leaders influence the development of this new organizational focusing.

\section{Internal entrepreneurship and attitude in a team situation}

Internal Entrepreneurship is not limited to work teams (Imai 1986; Nonaka 1988; Jelinek and Litterer 1995; Haskins et al. 1998). Studies by Reich (1987) and Stewart (1989), but especially the ethnographic study by Stewart, reflect on Internal Entrepreneurship in the context of a work team whose main function is to offer products and services which respond to the urgent ever-changing demands of markets. Internal Entrepreneurship exists in all types of collectives. Imai (1986) studied the Kaizen Corporation in its entirety. Small business owners should give greater consideration to the leadership role that specifically contributes more to the innovation performance of the small business than their role as entrepreneurs. This could corroborate the results obtained from Japanese firms which suggest that a non-creative and entrepreneurial leader could produce a non-creative team and organization. This shows that the source of Kaizen's success would be the collaborative attitude among team and organizational members. Jelinek and Litterer (1995) proposed a model of organizational entrepreneurship. Nonaka
(1988) and Mourdoukoutas (1999) extended the notion of Internal Entrepreneurship to the level of a network in the workplace, which means the collective business capability of a network of organizations (in the workplace).

\subsection{Job satisfaction}

Job satisfaction is the combination of feelings and beliefs that workers hold in relation to their current jobs. Someone with a high level of satisfaction will generally like their job; they feel that they are being fairly treated and believe that the job has many desirable facets (Jones et al. 1999). The satisfaction at work has been characterized as a positive or pleasing emotional state which emerges as the result of evaluating one's work or experiences in the workplace (Locke 1976). Job satisfaction is the result of workers' perceptions of "how well their job provides for those things that are considered important." Within the field of organizational behavior, it is generally recognized that job satisfaction is the most important and most frequently studied attitude. Studies show that there are many factors which affect the level of job satisfaction (Mitchell and Larson 1987). In an organizational context, there are usual factors such as the job itself, bonuses, supervision, work in teams, and working conditions (Smith et al. 1969). In our study, we will focus on the factors which are relevant within a team context and which can be influenced by the behavior of team leaders.

In general, it is desirable for team members to be satisfied with their jobs for at least two reasons. First, it is likely that satisfied members will contribute more to the team and will be committed to the social culture promoted by the organization - this behavior is not a requirement but it contributes toward and is necessary for team efficiency (Organ 1988). Team members who are satisfied with their jobs are capable of fulfilling their duties above all other things, which could vary between doing overtime when necessary and coming up with truly creative ideas, as well as overcoming obstacles to see these ideas through (even when doing so does not strictly form part of their job), as well as going out of their way to help colleagues of lesser or greater rank (even when doing so implies considerable personal sacrifice) (George and Brief 1992). Therefore, job satisfaction is an essential requisite in terms of attitude for extending their 
previously required capacities (Stewart 1989). A second reason for making sure that employees are satisfied is that they will be less likely to leave their jobs (Mobley 1977). When a member leaves the firm, it may damage the group's synergy due to the loss of experience and the necessary knowledge for cooperation which the team members have acquired through working together, such as knowledge of the team and its environment. Thus excessive turnover limits information on the team's synergetic capacity, which is crucial to continuous progress in the process of Internal Entrepreneurship (Slevin and Covin 1992).

Entrepreneurship in teams is based on an internal market activity of an informal nature, which depends on voluntary contributions from its employees (Stewart 1989). A lack of team satisfaction among team members can make the development of this informal, internal market activity impossible. Internal market activity helps members to learn how to work in a team. It also helps to generate specific team skills. It is these internally nurtured teams that are most collectively business-orientated. Consequently, from this perspective, job satisfaction is an extremely important factor in terms of attitude which helps to create conditions for Internal Entrepreneurship. In short, job satisfaction not only helps to create the necessary passion for collective synergism, but also helps to lay the foundations in the team's members for unique shared knowledge on themselves, on others, on their jobs, on the team as a whole, and on the job market. More importantly, job satisfaction provides opportunities for team members to accumulate experience and learn the necessary skills for effective and efficient cooperation with others. All this is indispensable for a final "gestation effect" on a collective level (Haskins et al. 1998).

Therefore following on from the extant literature as outlined above, the following hypothesis was tested:

Hypothesis 1 Job satisfaction is directly and positively associated with the level of Internal Entrepreneurship.

\subsection{Commitment to the team}

Many factors influence commitment to the organization. These include age, occupation, engagement, means of control, work projects, and the kind of relations present in the workplace (Luthans et al.
1987). Under this assumption, we could define organizational commitment as the consequence of the influence on the individual of a strong desire for permanence and a great will to maintain a high level of effort within the organization, together with the acceptance of the organization's values and objectives (Mowday et al. 1982). We will adapt the definition of organizational commitment to define commitment to the team. Commitment to the team is seen as the group of feelings, sensations, and beliefs held by members toward the team as a whole. Committed team members believe in what the team is doing, are proud of what the team represents, demonstrate a high level of loyalty, and have a deep sense of companionship (Haskins et al. 1998). It is therefore more likely for team members to act according to a sense of duty above all else to help their team and, at the same time, it is less likely that they will leave their jobs (Mathieu and Zajac 1990).

Among the many factors of attitude which are relevant to team members, commitment is also one of the most widely studied. As an important component in the group process, commitment reflects feelings of identification of members with their team and the extent of union within the group in carrying out tasks and reaching objectives. Differently to group cohesion, which is an essential property of the group as a whole, commitment can reflect an individual's attitude both toward a task and the group objective. Studies carried out on the relations between commitment and effectiveness of and within the group are not entirely convincing (Bettenhausen 1991). However, many studies show positive relations between commitment and absenteeism (Zaccaro and Collins 1988), and between commitment and group cohesion, another important component in the group process (Bettenhausen 1991; Cohn and Bailey 1997).

Commitment is also an emotional link between the individual and the group. Some theoreticians (Farrell and Rusbult 1981; Moreland and Levine 1982), claim that commitment depends mainly on the results (benefits or costs) associated with members of the group, in comparison with available results on real or potential members from other groups. Other theoreticians argue that commitment depends principally on the importance the individual attaches to the group for their social identity (Tajfel and Turner 1986). A basic need for personal improvement leads individuals to feel greater commitment toward the group (Moreland 
and Levine 1982). In general, people who have a strong feeling of commitment with the group are worried about others' wellbeing. As a result, they should devote greater effort to detecting and diagnosing the group's problems, defects, and weaknesses in their current jobs and look for better ways of doing their job and serving the group. In terms of entrepreneurship, Internal Entrepreneurship must be a voluntary and passionate activity of a morally valued work community (Stewart 1989) which is not only endowed with opportunities for personal growth among team members but can also satisfy their needs (Maslow 1943). Internal Entrepreneurship does not arise out of coercion or contracts. It does, on the other hand, arise out of individuals who are highly committed and constantly work to the limit of their possibilities. We suggest that such a passion arises out of satisfaction and individual commitment to and for the team, which leads the individual to go above and beyond the call of duty (George and Brief 1992) and build on their previous skills to serve the group. Thus, the commitment of members both toward the team and achieving job satisfaction, are two essential requisites of attitude for Internal Entrepreneurship in work teams.

Therefore the following hypothesis was tested:

Hypothesis 2 The commitment of members to the team is directly and positively associated with the level of Internal Entrepreneurship.

\section{Methodology}

\subsection{Sample}

The selection of firms to be studied was taken from the Company Directory ARDÁN, provided by the Institute of Small and Medium-Sized Firms. Among the quantitative criteria which can be used for classifying firms according to size, we used the criteria established under the Fourth Directive 78/ 660/European Union, taking into account the recommendations of the European Commission.

With regard to the sectors, these have been grouped into two large blocks: Industry, Construction, and Commerce on the one side and the remaining services on the other, with a distribution of $51 \%$ for the first block and $49 \%$ for the second. Such a grouping is consistent with data provided by the Department of
Management for Support of SMEs (statistics and publications section) which, in a document created on 27/1/2004 from information obtained via the National Institute of Statistics and revised in 2004, establishes a percentage distribution of $50.36 \%$ for the sectors of Industry, Construction, and Commerce and $49.64 \%$ for the Other Services sector.

\subsection{Overview and procedure}

All information was gathered over a 3-month period through face-to-face interviews. Such a decision was taken after analyzing two facts: problems encountered during previous research and the structure of the questionnaire. Another factor which greatly influenced this decision was that we thought it appropriate to interview two different sections which make up work teams: on the one hand the company owner and on the other the collaborative team members (two people were interviewed from each firm for this study). To cover the objectives of this study, we gathered opinions from 114 firms and 228 collaborators (members of managing teams) of these firms.

\subsection{Measures}

The questionnaire, designed using criteria whose methodology had been successfully tested on previous occasions and used by authors such as Kantis et al. (2002), Flores (2003), and Ribeiro (2003), was pretested by a group of experts made up of professors and researchers from some top universities in Spain. People from the University Complutense of Madrid and the University Autonoma of Barcelona from two different fields, that is, researchers in the topic being analyzed and others from the area of applied statistics in social sciences. After hearing suggestions from this group of experts, we proceeded with our research.

\subsection{Statistical analyses}

The general aim of our study is the analysis of the influence of the different variables of attitude on Internal entrepreneurship. The variables included in our research cannot be directly observed in an organization. However, it is possible to define, a priori, a series of variables which act as indirect measurements of the latent variables. To develop a 
successful model that includes latent variables, it is necessary to consider a wide-ranging group of potential measurements of factors to subsequently select a much reduced number which contains all information which is relevant to the latent factor, without introducing an excessive number of variables. Once these groups have been decided, a very concrete model using structural simultaneous equations is estimated, which includes just one latent variable (the factor to be analyzed) and all other associated observable variables.

Every causal model, and particularly the LISREL model (Linear Structural Relations) used in our research, consists of a group of lineal structural equations with latent variables and two groups of measurement equations for this group, which are dependent on other observable variables. The model is a structure of causal relations between the latent variables, and it supposes that the variables observed are indicators or symptoms of those variables. Three characteristics differentiate this method from other similar ones within multivariable analysis: (a) the model presents the existence of a causal structural relation between the variables, and not a mere statistical association. (b) The latent variables sometimes appear as lineal compounds of observed variables and as intermediary variables in the causal chain. (c) The method enables us to take into consideration the error of measurement which is produced as a consequence of the inadequacy of the indicator for the concept analyzed. This gives us the necessary flexibility to relate each variable to different concepts, providing estimates of the likelihood of success in such a selection. Thus, we prefer this model to a multiple regression model for the purposes of our research.

Therefore, the model has as many equations as it does observable variables and each one has the following form:

OBSERVABLE $=\lambda_{x 1 i} *$ LATENT $+\delta_{i}$

where $\delta_{\mathrm{i}}$ are normal, independent, and identically distributed variables.

\section{Findings}

The measures are considered as having acceptable reliability (Nunnally and Bernstein 1994). Results obtained when evaluating the variables of attitude of team members showed significant differences between the vision held by businessmen and that of the members themselves. The results were structured according to the significance tests established by Wilcoxon, Mann-Whitney, and Kruskal-Wallis. In this section, we will look at the study in terms of the firm's entrepreneurial nature and the sector where the firm's activity takes place. These analyses will only be carried out in cases where there are significant differences, that is, those differences where $p$-values are smaller than or equal to 0.01 . The impact and effect of variables of behavior on team members, the style of leadership applied by the company owner and the existence of Internal Entrepreneurship in the firm will be the object of further studies.

\subsection{Analysis of the factors}

Figure 1 presents the results of the estimation of the measurement model for the confirmatory factorial analysis of the job satisfaction variable.

The higher standardized coefficient values correspond to the following items (for members of the firms):

PDM1_6/PDM1_7: Work in teams.

Is it normal to work in teams in your firm?

Do you like working in teams?

PDM1_10: Carrying out additional work.

Do you carry out additional work (overtime) when you are required to do so to meet a deadline?

PDM1_11: Personal style of management.

Do you consider the style of management employed by the leader to be adequate?

Given that the values obtained for PDM1_6 and PDM1_7 have identical value, and we consider that the second one provides us with more information, we will use this one as our model. In this model, the variables that appear are referred to as:

- SATISF_1 = PDM1_7 Work in teams

- SATISF_2 = PDM1_10: Carrying out additional work

- SATISF_3 = PDM1_11: Personal style of management 
Fig. 1 Job satisfaction

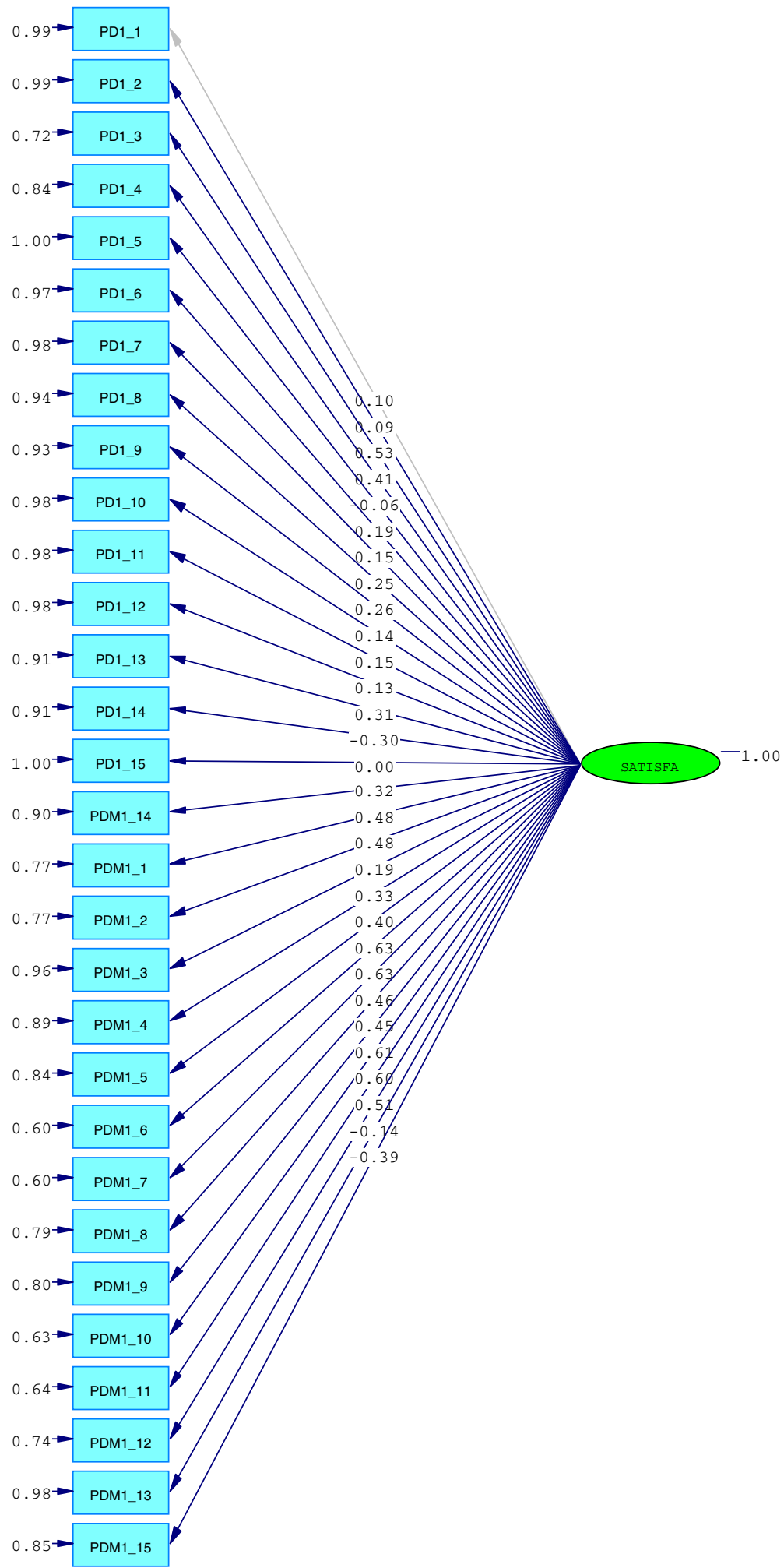


Figure 2 shows the outcomes of the estimations from the measurement model for the confirmatory factorial analysis of the commitment to the team variable.

The higher standardized coefficient values correspond to the following items (for the businessmen):

PD2_1: Belonging to the group.

Do you consider that members possess a strong desire to belong to the group?

PD2_2: Group effort.

Is there a high level of willingness to put in a great deal of effort in the name of the work team?

PD2_11: Diagnosis.

Is enough or a large amount of time spent on detecting and diagnosing problems in the group?

In our model, these variables appear as:

- COMPRO_1 = PD2_1: Belonging to the team

- COMPRO_2 = PD2_2: Group effort

- COMPRO_3 = PD2_11: Diagnosis

\section{Modelization}

The first structural factor analyzed (see Fig. 3) is that which relates latent factors of attitude (job satisfaction (SATISF) and commitment to the team (COMPRO) with the existence of Internal entrepreneurship.

The structural part of the model can be expressed as:

$\mathrm{EMPCOL}=\gamma_{11} \mathrm{SATISF}+\gamma_{12} \mathrm{COMPRO}_{i}+\zeta_{1}$

The estimation given for our data is:

$$
\begin{aligned}
\mathrm{EMPCOL}= & \underset{(3.32)}{0.40} * \mathrm{SATISF}_{i}+\underset{(2.22)}{1.2} * \mathrm{COMPRO}_{i} \\
& +\hat{\zeta}_{1}
\end{aligned}
$$

Between brackets and underneath each coefficient, the value of statistic $t$ is shown, which is associated with the nullity contrast of the coefficient. This is distributed equally as a $t$ for Student with 25 degrees of freedom, where the value of the Chi-squared statistic is 31.20 and where there is an associated p-value of 0.182 .

The model shows that commitment to the team and job satisfaction positively affects the level of Internal Entrepreneurship in the organization. Moreover it can be observed that the impact of commitment to the team (whose associated coefficient is 1.20), is far superior to that of job satisfaction (with an estimated coefficient of 0.40 ). As they are standardized coefficients, it is possible to compare values and we can state that commitment to the team has an impact three times greater than that of job satisfaction. The validity of the model is confirmed by the high level of goodness of fit (0.91) and the average quadratic root error of 0.09 .

As the main objective of this study, we initially proposed taking a closer look at the conceptual content of entrepreneurial spirit within the firm to be able to analyze the capacity to transmit this spirit from the unique and individual businessperson (entrepreneur) to the group, the collective owner (the work team). We proposed, then, discovering the variables of attitude that, from the point of view of collaborators (team members) and of the style of management adopted by businessmen (leaders) determine the right conditions for confirming the possibility of the existence of Internal entrepreneurship in the firm.

\section{Discussion and conclusions}

Entrepreneurship is not the sole province of the company's founder or its top managers. We propose that small business innovation could come from another important source, the collective efforts of the entire firm, and not only the ingenuity or creativity of the individual entrepreneur. Entrepreneurial efforts of a collective are focused on countless small innovative ideas that help members to stretch past their previous abilities. Collaboration among team or organizational members leads to continuous innovations, named by us, Internal Entrepreneurship. We can accept the fact that job satisfaction and commitment to the team are factors which directly and positively affect Internal Entrepreneurship, thus confirming the hypothesis we started from. See Fig. 4.

The limitations of our work are in the noninclusion of results necessary to reflect sectorial behaviors. In our opinion, comparisons may be made between the data collected for our study and other data from more traditional enterprises to highlight differences and reveal short-term actions to be carried out to gain competitiveness. Although we have referred to small and medium-sized organizations, future research should examine a larger sample that 
Fig. 2 Commitment to the team

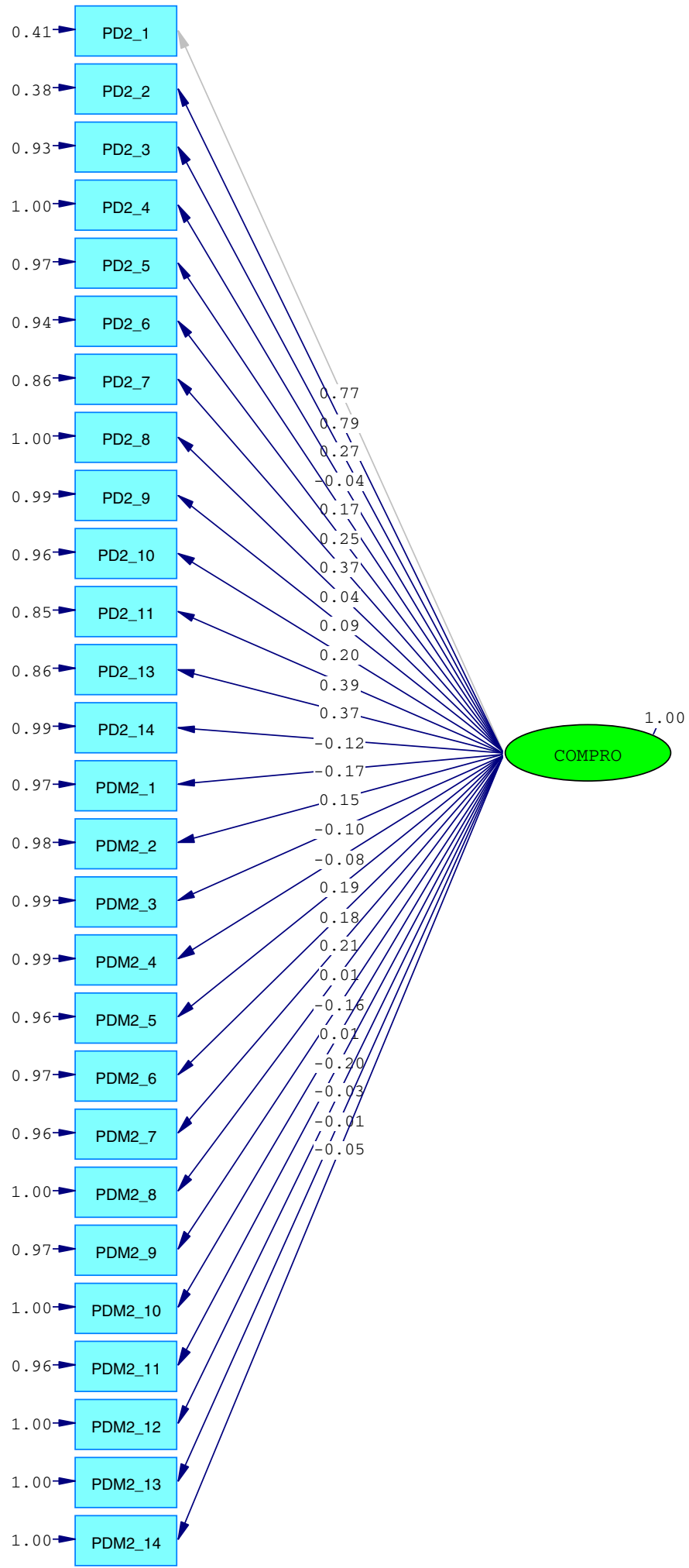




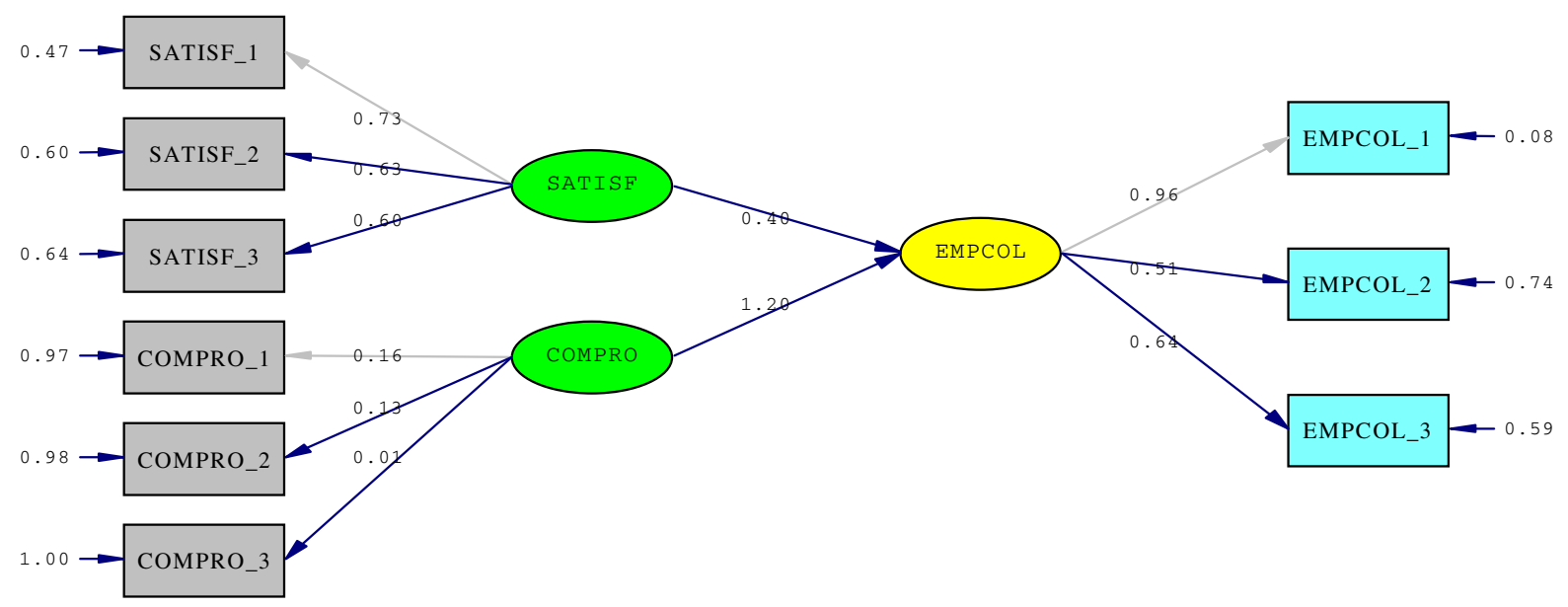

Fig. 3 Model of relations between variables of attitude and collective entrepreneurship

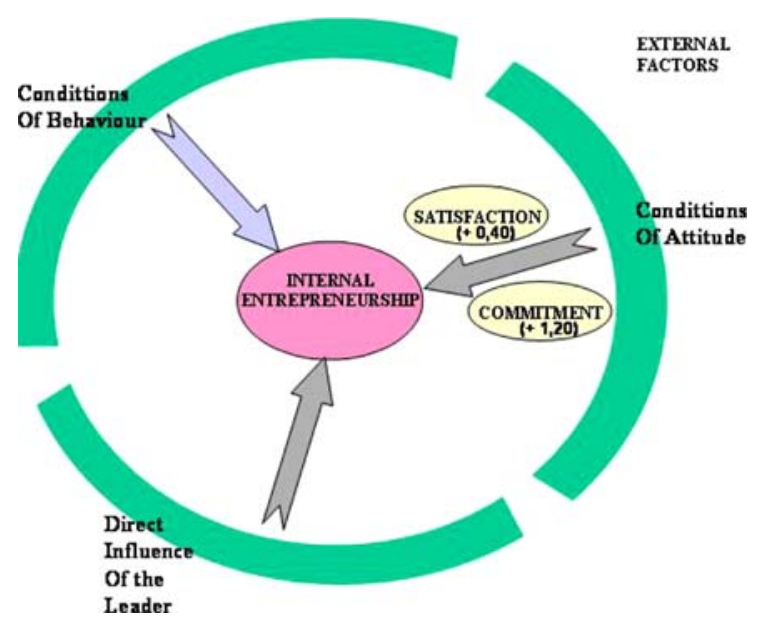

Fig. 4 Factors of the existence of collective entrepreneurship

would allow us to gather more quantitative data. There may be a need to review the way in which policy-makers undertake investigations concerning firms' strategy competitiveness and entrepreneurship. This would involve, for example, undertaking personal interviews, incorporating firms of different sizes and, more importantly, taking into account the varying degrees of strategy commitment within sectors. The existence of conduct factors that affect the behavior and development of the team, as well as the different styles of leadership applied by the company owner in the management of the organization, will shape our future lines of investigation. In this way, we will be able to complete our study of the area and define in their entirety the main factors which affect Internal Entrepreneurship in a work team environment.

\section{References}

Bennis, W., \& Biederman, P. W. (1998). Organizing genius: The secrets of creative collaboration. Reading, MA: Addison-Wesley.

Bettenhausen, K. L. (1991). Five years of groups research: What we have learned and what needs to be addressed. Journal of Management, 17, 345-381.

Carland, J., Hoy, F., Boulton, W. R., \& Carland, J. (1984). Differentiating entrepreneurs from small business owners: A conceptualization. Academy of Management Review, 9, 354-359.

Casson, M., \& Wadeson, N. (2007). The Discovery of Opportunities: Extending the Economic Theory of the Entrepreneur. Small Business Economics, 28, 285-300.

Cohn, S. C., \& Bailey, D. E. (1997). What makes teams work: Group effectiveness research from the shop floor to the executive suite. Journal of Management, 23, 239-290.

Darroch, J., Miles, M. P., \& Buisson, T. (2005). Patenting strategy of entrepreneurial orientated firms in New Zealand. International Entrepreneurship and Management Journal, 1, 45-59.

Dyer, W. G. (1994). Potential contributions of organizational behavior to the study of family-owned businesses. Family Business Review, 7, 109-131.

Farrel, D., \& Rusbult, C. E. (1981). Exchange variables as predictors of job satisfaction, job commitment, and turnover: The impact of rewards, cost, alternatives and investments. Organiuzational Behaviour and Human Performance, 28, 78-95.

Flores, P. (2003). Curso: Soy capaz de crear mi propia empresa. Lima: Instituto de Libre Empresa. 
Fukugawa, N. (2006, October). Determining factors in innovation of small firm networks: A case of cross industry groups in Japan. Small Business Economics, 27, 181-193.

Gartner, W. B. (1989). Some suggestions for research on entrepreneurial traits and characteristics. Entrepreneurship Theory and Practice, 14(1), 27-38.

Gartner, W. B. (1990). What are we talking about when we talk about entrepreneurship? Journal of Business Venturing, 5, $15-28$.

George, J. M., \& Brief, A. P. (1992). Feeling good-doing good: A conceptual analysis of the mood at work-organizational spontaneity relationship. Psychological Bulletin, 112, 310-329.

Govindarajan, G., \& Tremble, C. (2006). Ten Rules for Strategic Innovators Collection. Harvard Business Review, January.

Haskins, M. E., Liedtka, J., \& Rosenblum, J. (1998). Beyond teams: Toward an ethic of collaboration. Organizational Dynamics, 26(4), 34-50.

Hewitt-Dundas, N. (2006). Resource and capability constraints to innovation in small and large plants. Small Business Economics, 26, 257-277.

Huse, M., Neubaum, D. O., \& Gabrielsson, J. (2005). Corporate innovation and competitive environment. International Entrepreneurship and Management Journal, 1, 313-333.

Imai, M. (1986). Kaizen: The key to Japan's competitive success. New York: Random House Business Division.

Jelinek, M., \& Litterer, J. A. (1995). Toward entrepreneurial organizations: Meeting ambiguity with engagement. Entrepreneurship Theory and Practice, 19(3), 137-168.

Johannisson, B. (2003). Entrepreneurship as a collective phenomenon. In E. Genescà et al. (Eds.), Creación de empresas. Entrepreneurship. Homenaje al profesor José María Veciana (pp. 87-109). Barcelona: Servei de Publicacions de la UAB.

Jones, G. R., George, J. M., \& Hill, C. W. (1999). Contemporary management. Boston: McGraw-Hill.

Kantis, H., Ishida, M., \& Komori, M. (2002). Empresarialidad en economías emergentes: Creación y desarrollo de nuevas empresas en América Latina y el Este de Asia. New York: Banco Interamericano de desarrollo.

Locke, E. A. (1976). The nature and causes of job satisfaction. In M. D. Dunnete (Ed.), Handbook of industrial and organizational psychology (pp. 1297-1349). Chicago, IL: Rand McNally.

Luthans, F., Baack, D., \& Taylor, L. (1987). Organizational commitment: Analysis of antecedents. Human Relations, 40, 219-236.

Maslow, A. H. (1943). A theory of human motivation. Psychological Review, 50, 370-396.

Mathieu, J. E., \& Zajac, D. M. (1990). A review and metaanalysis of the antecedents, correlates, and consequences of organizational commitment. Psychological Bulletin, 108, 171-194.

McMullen, J. S., Plummer L. A., \& Acs, Z. J. (2007). What is an Entrepreneurial Opportunity? Small Business Economics, 28, 273-283.

Mitchell, T. R., \& Larson, J. R. (1987). People in organizations: An introduction to organizational behaviour. New York: McGraw-Hill.
Mobley, W. H. (1977). Intermediate linkages in the relationship between job satisfaction and employ turnover. Journal of Applied Psychology, 62, 237-240.

Moreland, R. L., \& Levine, J. M. (1982). Socialization in small groups: Temporal changes in individual-group relations. In L. Berkowitz (Eds.), Advances in experimental social psychology (pp.137-192). New York: Academic Press.

Mourdoukoutas, P. (1999). Collective entrepreneurship in a global economy. Westport, CT: Quorum Books.

Mowday, R. T., Porter, L. W., \& Steers, R. M. (1982). Employeeorganization linkages. New York: Academic Press.

Nonaka, I. (1988). Toward middle-up-down management: Accelerating information creation. Sloan Management Review, 29(3), 9-18.

Nunnally, J. C., \& Bernstein, I. H. (1994). Psychometric theory (3rd ed.). New York: McGraw-Hill.

Organ, D. W. (1988). Organizational citizenship behaviour: The good soldier syndrome. Lexington, MA: Lexington Books.

Pinchot, G. III (1985). Intrapreneuring. New York, N.Y.: Harper \& Row.

Reich, R. B. (1987). Entrepreneurship reconsidered: The team as hero. Harvard Business Review, 65(3), 77-83.

Ribeiro, D. (2003). The impact of consulting service on Spanish firms. Journal of Small Business Management, 41, 409-416.

Rosa, P., \& Scott, M. (1999). The prevalence of multiple owners and directors in the SME sector: Implications for our understanding of start-up and growth. Entrepreneurship and Regional Development, 11, 21-37.

Schumpeter, J. A. (1934). The Theory of economic development. Cambridge, MA: Harvard University Press.

Scott, H. (1999). Our future requires collaboration leadership. Workforces, 78(12), 30-34.

Scott, A. J. (2006) Entrepreneurship, innovation and industrial development: Geography and the creative field revisited. Small Business Economics, 26, 1-24.

Sharma, P., \& Chrisman, J. J. (1999). Reconciling the definitional issues in the field of corporate entrepreneurship. Entrepreneurship Theory and Practice, 23(5), 11-27.

Slevin, D. P., \& Covin, J. G. (1992). Creating and maintaining high-performance teams. In C. A. Kent, D. L. Sexton, \& K. H. Vesper (Eds.), Encyclopaedia of entrepreneurship (pp. 358-386). Englewood Cliffs, NJ: Prentice-Hall.

Smith, P. C., Kendall, L. M., \& Hulin, C. L. (1969). The measure of satisfaction in work and retirement. Chicago: Rand McNally.

Stevenson, H. H., \& Jarillo, J. C. (1990). A paradigm on entrepreneurship: Entrepreneurial management. Strategic Management Journal, 11, 17-27.

Stewart, A. (1989). Team entrepreneurship. Newbury Park, CA: Sage.

Tajfel, H., \& Turner, J. C. (1986). The social identity theory of intergroup behaviour. In S. Worchel, \& W. G. Austin (Eds.), Psychology of intergroup relations (pp. 7-24). Chicago: Nelson-Hall.

Westhead, P., \& Wright, M. (1998). Novice, portfolio and serial founders in rural and urban areas. Entrepreneurship Theory and Practice, 22(4), 63-100.

Zaccaro, S. J., \& Collins, T. T. (1988). Excused and unexcused absenteeism in normative organizations: Effects of 
organizational commitment, rank, and interaction process. Group and Organization Studies, 13, 81-99.

Zahra, S. A. (1993). A conceptual model of entrepreneurship as firm behaviour: A critique and extension. Entrepreneurship Theory and Practice, 17(4), 5-21.
Zampetakis, L. A., \& Moustakis, V. (2006). Linking creativity with entrepreneurial intentions: A structural approach. International Entrepreneurship and Management Journal, 2, 413-428. 